\title{
Efektifitas Antibakteri Ekstrak Daun Pegagan (Centella Asiatica) Terhadap Pertumbuhan Bakteri Staphylococcus aureus
}

\author{
Siti Fatimah ${ }^{\mathrm{a}, 1^{*}}$, Yuliana Prasetyaningsiha, ${ }^{\mathrm{a}}$, Ratih Widi Astutia, 3 \\ aSTIKes Guna Bangsa Yogyakarta, Jl.Padjajaran, Ngringin, Condongcatur Depok Sleman Yogyakarta, Indonesia \\ ${ }^{1}$ siti.fatimah.gunabangsa@gmail.com*; ${ }^{2}$ yulianaprasetya@gmail.com; ${ }^{3}$ ratihwidi@gmail.com \\ *korespondensi penulis
}

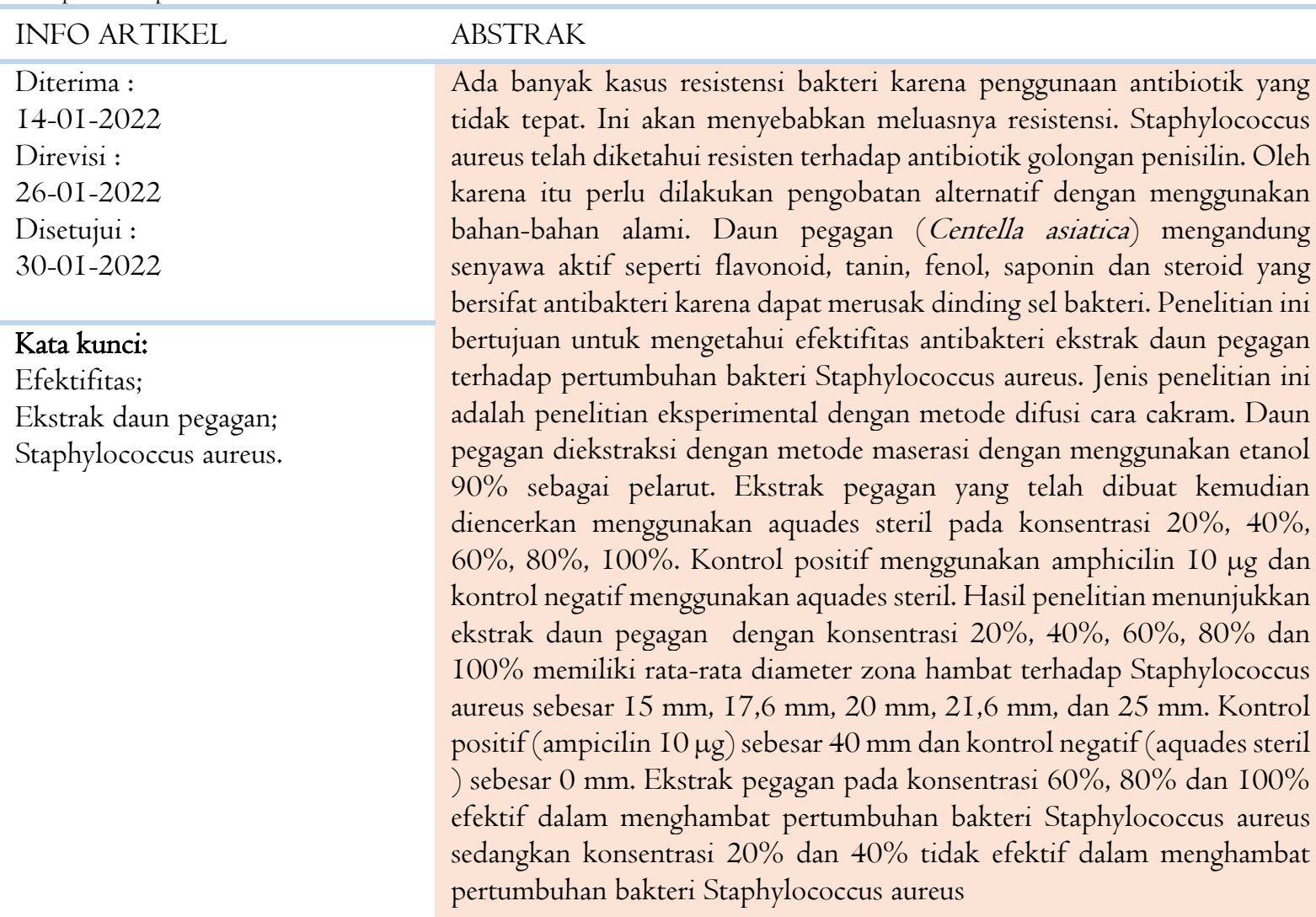

Key word:

effective;

pegagan leaf extract;

Staphylococcus aureus.

\section{ABSTRACT}

There are many cases of bacterial resistance due to inappropriate use of antibiotics. This will cause widespread resistance. Staphylococcus aureus has been known to be resistant to penicillin class antibiotics. Therefore it is necessary to do alternative medicine using natural ingredients. Pegagan (Centella asiatica) leaves contain active compounds such as flavonoids, tannins, phenol, saponins and steroid which are antibacterial because they can damage bacterial cell walls. This study aims to determine the antibacterial effectiveness of pegagan leaf extract against the growth of Staphylococcus aureus bacteria. This type of research is an experimental study with the disc diffusion method. Pegagan leaves were extracted by maceration method using $90 \%$ ethanol as solvent. The pegagan extract that had been made was then diluted using sterile distilled water at concentrations of $20 \%, 40 \%, 60 \%, 80 \%$, I00\%. Positive control used 10 $\mu \mathrm{g}$ amphicillin and negative control used sterile distilled water. The results showed that the pegagan leaf extract with concentrations of $20 \%, 40 \%$, $60 \%, 80 \%$ and $100 \%$ had an average diameter of the inhibition zone against Staphylococcus aureus of $15 \mathrm{~mm}, 17.6 \mathrm{~mm}, 20 \mathrm{~mm}, 21.6 \mathrm{~mm}$, and $25 \mathrm{~mm}$. The positive control (ampicillin I0 $\mathrm{gg}$ ) was $40 \mathrm{~mm}$ and the negative control (sterile distilled water) was $0 \mathrm{~mm}$. Pegagan extract at concentrations of $60 \%, 80 \%$ and $100 \%$ was effective in inhibiting the 
growth of Staphylococcus aureus bacteria, while concentrations of $20 \%$ and $40 \%$ were not effective in inhibiting the growth of Staphylococcus aureus bacteria.

This is an open access article under the CC-BY-SA license.

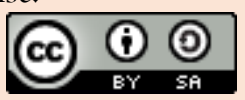

\section{Pendahuluan}

Penyakit infeksi bakteri merupakan salah satu permasalahan besar yang dihadapi oleh negara-negara berkembang seperti Indonesia, walaupun telah ada sejumlah agen antibakteri yang digunakan untuk pengobatan penyakit infeksi bakteri ini. Maka dari itu, sangat diperlukan adanya pembelajaran lebih lanjut tentang zat kimia yang didapatkan secara alami agar agen antibakteri yang digunakan lebih aman bagi masyarakat (Karuppiah, dkk., 20I2). Staphylococcus aureus merupakan bakteri yang cepat menjadi resisten terhadap banyak obat antimikroba salah satunya antibiotik dan menimbulkan persoalan terapi yang sulit (Jawetz, dkk., 2013). Resistensi bakteri terhadap antibiotik adalah perubahan kemampuan bakteri hingga menjadi kebal terhadap antibiotik tersebut. Staphylococcus aureus yang telah resisten terhadap siprofloksasin mencapai $37 \%$. Selain itu Staphylococcus aureus juga resisten terhadap banyak penisilin (penisilin G, ampisilin, tikarsilin, piperasilin dan obat-obat serupa). Presentasi bakteri Staphylococcus aureus yang telah resisten terhadap metisilin (methicilin resistans S.aureus, MRSA) cukup tinggi di asia (Eliott, dkk., 20I3). Penggunaan bahan alami kini semakin banyak meningkat pemanfaatannya sebagai obat tradisional karena obat tradisional banyak digunakan, mudah didapat, ekonomis dan memiliki efek samping yang relatif rendah (Alfianthi, dkk., 2016). Salah satu keanekaragaman hayati yang memiliki potensi untuk dikembangkan sebagai obat tradisional adalah daun pegagan (Centella asiatica). Pegagan merupakan tanaman liar yang banyak tumbuh di perkebunan, ladang, tepi jalan, serta pematang sawah. Tanaman ini berasal dari daerah Asia tropik, tersebar di Asia Tenggara, termasuk Indonesia, India, Republik Rakyat Cina, Jepang dan Australia kemudian menyebar ke berbagai negara-negara lain. Nama yang biasa dikenal untuk tanaman ini adalah daun kaki kuda dan antanan. Tanaman ini sudah banyak diketahui oleh masyarakat sebagai tanaman obat misalnya membersihkan darah, melancarkan peredaran darah, peluruh kencing (diuretika), penurun panas (antipiretika), menghentikan pendarahan (haemostatika), meningkatkan syaraf memori, anti bakteri, tonik, anti asma, anti inflamasi, hipotensif, insektisida, anti alergi dan stimulan (Muchtaromah, 20II).
Pegagan (Centella asiatica) merupakan salah satu tanaman yang digunakan sebagai obat. Salah satu manfaat yang bisa didapatkan dari pegagan (Centella asiatica) adalah antibakterinya. Manfaat antibakterinya didapatkan karena pegagan (Centella asiatica) mengandung zat antibakteri, diantaranya adalah flavonoid, saponin, tanin, fenol dan steroid (Sutrisno, dkk., 20I4)

Berdasarkan uraian latar belakang di atas maka peneliti memilih daun pegagan (Centella asiatica) sebagai subjek penelitian karena daun pegagan mengandung flavonoid, saponin, tanin, fenol dan steroid yang dapat menghambat pertumbuhan bakteri. Peneliti ingin mengetahui efektivitas bahan aktif dalam daun pegagan (Centella asiatica) tersebut sebagai agen antibakteri dalam menghambat pertumbuhan bakteri Staphylococcus aureus.

\section{Metode}

I. Alat dan Bahan

Bahan yang digunakan dalam penelitian ini adalah daun pegagan (Centella asiatica) yang diperoleh dari area pesawahan Desa Nguwet, Kecamatan Kranggan, Kabupaten Temanggung Jawa Tengah, suspensi bakteri Staphylococcus aureus, $\mathrm{NaCl}$ fisiologis 0,85\%, media Muller Hinton Agar, Etanol 90\%, Mc Farland, aquadest steril, antibiotik Amphicilin $10 \mu \mathrm{g}$. Alat-alat digunakan dalam penelitian ini adalah oven (Memmert $(\mathbb{)})$, autoclave (GEA ${ }^{\circledR}$ YXQG-0I, inkubator (Memmert ${ }^{\circledR}$ ), cawan petri, pinset, neraca, lampu spiritus, ose steril penggaris, tabung reaksi, pipet steril, mikropipet, erlenmeyer, gelas kimia, kapas lidi steril, kertas cakram, kasa steril,.

2. Jalannya Penelitian

a. Pembuatan Simplisia Daun Pegagan (Lolutung, dkk., 2015)

Daun pegagan diambil sebanyak I kg yang diperoleh dari area persawahan di Kabupaten Temanggung, tanaman ini dipilih daun yang segar, tidak terlalu muda, tidak terlalu tua dan bebas dari hama penyakit. Daun pegagan dicuci dengan air bersih, kemudian dikeringkan di bawah sinar matahari yang ditutupi dengan kain hitam

b. Pembuatan ekstrak daun pegagan (Lolutung, dkk., 2015) 
Serbuk daun pegagan kering 276,9I gram diekstrak dengan metode maserasi menggunakan pelarut etanol $90 \%$. Hasil ekstrak daun pegagan ditimbang didapatkan hasil ekstrak sebanyak 18,20 gr dan selanjutnya dibuat pengenceran

c. Pembuatan Media Muller Hinton Agar (Kuswiyanto,2014) Ditimbang bahan Muller Hinton Agar sebanyak 7,6 gram dilarutkan dengan 200 $\mathrm{ml}$ aquades. Media Muller Hinton Agar dimasukkan ke dalam autoclave selama I5 menit pada suhu $12 \mathrm{I}^{\circ} \mathrm{C}$ untuk disterilisasi. Media dituangkan ke dalam cawan petri masing-masing $20 \mathrm{ml}$ kemudian media disimpan di dalam lemari pendingin

d. Pembuatan $\mathrm{NaCl}$ Fisiologis 0,85\% (Kuswiyanto, 20I4)

Ditimbang $\mathrm{NaCl}$ sebanyak 0,085gram dilarutkan dalam $\mathrm{I} 0 \mathrm{ml}$ aquades, $\mathrm{pH}$ dibuat menjadi 7,0 dengan menambahkan $\mathrm{NaOH}$ 0,I $\mathrm{N}$ atau HCL O,I lalu disterilisasi dengan autoclave selama 15 menit pada suhu $12 \mathrm{I}^{\circ} \mathrm{C}$ dengan tekananIatm (Kuswiyanto, 20I4)

e. Persiapan bakteri Staphylococcus aureus I). Pengecatan gram (Kuswiyanto, 20I4) Diambil 3 ose biakan bakteri Staphylococcus aureus dan difiksasi di atas nyala api spiritus. Dilakukan pewarnaan gram, kemudian preparat diamati di bawah mikroskop dengan perbesaran 1000 kali.

2). Suspensi Bakteri (Kuswiyanto, 20I4)

Diambil satu ose koloni biakan murni bakteri Staphylococcus aureus pada natrium agar dan disuspensikan dengan $5 \mathrm{ml} \mathrm{NaCl}$ fisiologis $0,85 \%$ kemudian dikocok sampai keruh selama I-3 menit, dibandingkan dengan larutan standar kuman $10^{8} / \mathrm{CFU}$ (standar Mc Farland)

f. Pengenceran ekstrak daun pegagan Ekstrak daun pegagan dengan konsentrasi I00\% diencerkan dengan aquadest steril untuk mendapatkan larutan daun pegagan dengan konsentrasi 20\%, 40\%, 60\%, 80\% dan $100 \%$. Berikut adalah pengenceran ekstrak daun pegagan dapat dilihat pada tabel I

Tabel I. Pengenceran Ekstrak Daun

$$
\text { Pegagan }
$$

\begin{tabular}{cccc}
\hline $\begin{array}{c}\text { Ekstrak } \\
\text { Daun } \\
\begin{array}{c}\text { Pegagan } \\
(\mathrm{ml})\end{array}\end{array}$ & $\begin{array}{c}\text { Aquadest } \\
\text { Steril } \\
(\mathrm{ml})\end{array}$ & $\begin{array}{c}\text { Volume } \\
(\mathrm{ml})\end{array}$ & $\begin{array}{c}\text { konsen } \\
\text { trasi }\end{array}$ \\
\hline $\mathrm{I}$ & 0 & $\mathrm{I}$ & $\mathrm{I}$ \\
\hline 0,8 & 0,2 & $\mathrm{I}$ & $80 \%$ \\
\hline
\end{tabular}

\begin{tabular}{cccc}
\hline 0,6 & 0,4 & I & $60 \%$ \\
\hline 0,4 & 0,6 & I & $40 \%$ \\
\hline 0,2 & 0,8 & I & $20 \%$ \\
\hline
\end{tabular}

g. Persiapan kertas cakram (Putra, 2020)

Kertas cakram disk blank dicelupkan pada masing-masing konsentrasi ekstrak daun pegagan yaitu 20\%, 40\%, 60\%, 80\%, I00\% dan kontrol negatif aquadest

h. Penanaman bakteri (Kuswiyanto, 20I4) Kapas lidi steril dicelupkan ke dalam suspensi bakteri lalu digoreskan pada permukaan muller hinton agar hingga rata, kemudian kertas cakram yang sudah disiapkan diletakkan pada permukaan media muller hinton agar. Uji antibakteri ini dilakukan dengan menggunakan kontrol negatif aquadest steril dan kontrol positif ampicilinI0 $\mu \mathrm{g}$

i. Inkubasi ((Jawetz, dkk., 20I3).

Media MHA yang sudah ditanami bakteri Staphylococcus aureus dan diberi berbagai konsentrasi ekstrak daun pegagan kemudian diinkubasi pada suhu $37^{\circ} \mathrm{C}$ selama 24 jam

j. Pembacaan hasil

Pembacaan hasil dilakukan dengan mengukur diameter zona jernih di sekitar kertas cakram menggunakan penggaris berskala mm.

k. Analisa Data

Tingkat efektifitas antibakteri ekstrak pegagan dengan variasi konsentrasi $20 \%$, $40 \%, 60 \%, 80 \%$ dan $100 \%$ dapat ditentukan dengan mengukur presentase (\%) daya hambat menggunakan persamaan Oroh, dkk., (2015):

$\mathrm{E}=(\mathrm{D} / \mathrm{Da}) \times \mathrm{IOO}$

Dimana

E: Efektivitas antibakteri (\%),

D: Diameter zona hambat ekstrak daun pegagan $(\mathrm{mm})$.

Da: Diameter zona hambat antibiotika (mm). Menurut Oroh, dkk., (2015).

Efektifitas antibakteri dikelompokkan ke dalam 2 kelompok, yakni tidak efektif dan efektif, dapat dilihat pada tabel 2

Tabel 2. Pengelompokan efektivitas antibakteri menurut Oroh, dkk (2015)

\begin{tabular}{lrl}
\hline No & Persentase & Efektifitas \\
\hline $\mathrm{I}$ & $<50 \%$ & Tidak efektif \\
\hline 2 & $\geq 50 \%$ & efektif \\
\hline
\end{tabular}

\section{Hasil dan Pembahasan}

Penelitian ini dilakukan untuk mengetahui efektivitas ekstrak daun pegagan (Centella asiatica) terhadap pertumbuhan bakteri Staphylococcus 
aureus yang bersifat gram positif sebanyak 3 kali pengulangan menggunakan konsentrasi 20\%, 40\%, $60 \%$, 80\% dan 100\%. Daun pegagan dalam penelitian ini berasal dari area persawahan Desa Nguwet, Kecamatan Kranggan, Kabupaten Temanggung, Jawa Tengah. Daun Pegagan yang digunakan adalah daun yang berwarna hijau, tidak terlalu tua dan bebas dari hama penyakit. Alasan Peneliti menggunakan daun pegagan karena simplisia dan ekstrak etanol daun pegagan mengandung flavonoid saponin, tannin, fenol, dan terpenoid/steroid (Sutrisno., dkk 20I4) Simplisia daun pegagan dibuat di Temanggung dengan metode pengeringan di bawah sinar matahari dan ditutupi dengan kain hitam di atasnya untuk menghindari rusaknya senyawa kimia yang terkandung pada daun pegagan. Simplisia daun pegagan diekstraksi di Laboratorium Penelitian Pengujian Terpadu (LPPT) Universitas Gadjah Mada Yogyakarta. Hasil rendemen ekstrak etanol pegagan sebesar 6,57 \%. Hasil rendemen ini lebih besar apabila dibandingkan dengan penelitian Hapsari, dkk ( 2017) yang menghasilkan rendemen 5,9\%. Perbedaan ini diakibatkan karena pegagan yang digunakan berasal dari tempat yang berbeda, pegagan penelitian hapsari, dkk (2017) berasal dari daerah Magelang, sedangkan pegagan penelitian ini berasal dari daerah Temanggung. Rendemen ini menunjukkan banyaknya senyawa bioaktif yang larut dalam pelarut.

Penelitian ini menggunakan metode difusi cakram disk, Metode ini dipilih karena memiliki kelebihan yaitu prosedurnya mudah dan praktis untuk dilakukan dan dapat digunakan untuk melihat sensitivitas berbagai jenis mikroba terhadap antimikroba pada konsentrasi tertentu dan sering digunakan dalam uji kepekaan antibiotik dalam program pengendalian mutu (Lalamentik, 20I7). Pembacaan hasil pada metode difusi dengan cara mengukur adanya zona hambat atau zona jernih. Zona hambat merupakan daerah di sekitar cakram disk yang tidak ada pertumbuhan bakteri. Kelemahan dari metode difusi ialah hanya dapat mengetahui ada atau tidaknya zat dengan aktifitas antibakteri.

Ekstrak daun pegagan (Centella asiatica) mampu menghambat bakteri Staphylococcus aureus ditunjukkan dengan adanya zona hambat disekitar cakram disk pada media Muller Hinton Agar (MHA) karena kandungan tannin, flavonoid dan saponin fenol dan steroid yang terkandung dalam ekstrak pegagan (Sutrisno, dkk., 2017). Media MHA adalah media terbaik untuk pemeriksaan uji sensitivitas bakteri (Atmojo, 2016). Media MHA digunakan sebagai media uji antibakteri karena bakteri gram positif dan gram negatif dapat tumbuh dalam media MHA dan media ini sering digunakan dalam uji sensitivitas antibiotik, selain itu komposisi pada media ini cocok untuk uji sensitivitas, salah satunya yaitu tepung pati yang dapat menyerap racun yang dikeluarkan bakteri sehingga tidak menganggu antibiotik serta dapat mendukung pertumbuhan bakteri yang bersifat fakulatif anaerob yang patogen.

Diameter zona hambat/bening dengan variasi konsentrasi pada koloni bakteri dibandingkan dengan zona hambat/bening di sekitar cakram yang berisi kontrol positif menggunakan AmpicilinIO $\mu \mathrm{g}$ dan kontrol negatif menggunakan aquadest steril. Ampicilin digunakan sebagai kontrol positif karena antibiotik ini merupakan antibiotik yang efektif menghambat pertumbuhan bakteri gram positif seperti Staphylococcus aureus. Pengobatan Staphylococcus aureus menjadi semakin sulit karena munculnya strain methisilin resisten staphylococcus aureus (MRSA) yaitu bakteri Staphylococcus aureus yang resisten terhadap antibiotik sehingga ampicilin masih direkomendasikan sebagai antibiotik infeksi Staphylococcus aureus, sedangkan aquadest steril digunakan sebagai kontrol negatif karena tidak memiliki kemampuan menghambat pertumbuhan bakteri. Apabila zona hambat/bening yang dihasilkan oleh daun pegagan (Centella asiatica) lebih besar daripada kontrol positif maka daun pegagan lebih efektif sebagai antibakteri daripada kontrol positif secara in vitro, sedangkan apabila zona hambat/bening yang dihasilkan daun pegagan lebih kecil daripada kontrol positif maka daun pegagan kurang efektif sebagai antibakteri. Penggunaan kontrol negatif bertujuan untuk memastikan bahwa tidak ada efek antibakteri dari pelarut. Apabila kontrol negatif memiliki zona hambat/bening maka efek antibakteri pada pengenceran daun pegagan akan berkurang validitasnya.

Bakteri Staphylococcus aureus yang digunakan diidentifikasi dengan melakukan pewarnaan gram dan diamati morfologinya. Pada pengecatan gram Staphylococcus aureus berbentuk bulat dengan diameter I $\mu \mathrm{m}$, bergerombol seperti anggur, berwarna ungu kemerahan dan termasuk bakteri gram positif. Bakteri ini bersifat koagulase-positif dan DNAase positif (Elliot, 2013).

Hasil zona hambat ekstrak daun pegagan pada muller hinton agar dengan variasi konsentrasi terhadap bakteri Staphylococcus aureus dapat dilihat pada gambar I dan 2 


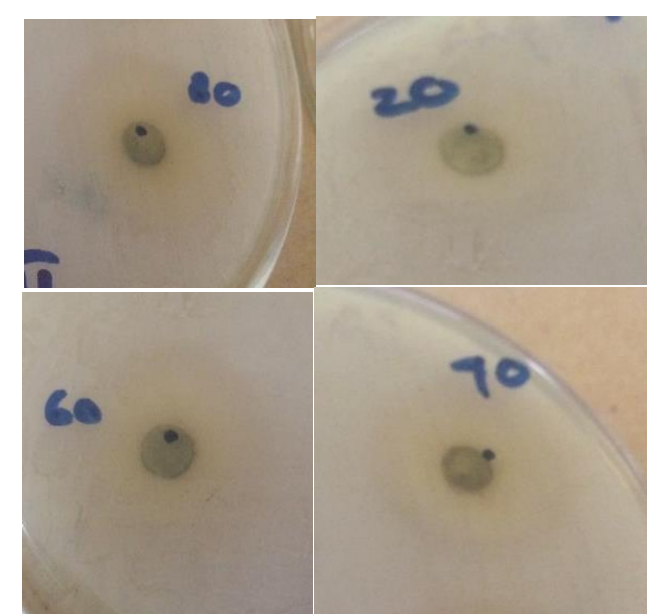

Gambar I. Hasil dari zona hambat ekstrak daun pegagan konsentrasi $20 \%, 40 \%$, 60\%, dan $80 \%$

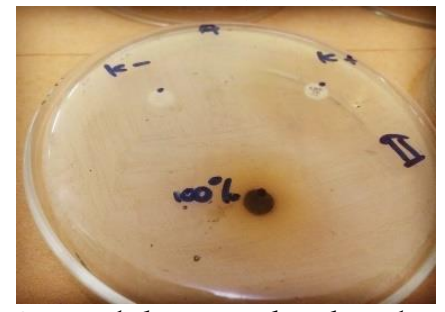

Gambar 2. Hasil dari zona hambat ekstrak daun pegagan konsentrasi 100\%, kontrol positif dan kontrol negatif.

Pembacaan hasil pada metode difusi dengan mengukur adanya zona hambat. Hasil uji daya hambat ekstrak daun pegagan yang telah dilakukan memiliki kemampuan dalam menghambat pertumbuhan bakteri Staphylococcus aureus yang ditunjukkan pada tabel 3 .

Tabel 3. Hasil Pengukuran Rata-rata Diameter

Zona Jernih Ekstrak Daun Pegagan (Centella asiatica) Terhadap Pertumbuhan Bakteri Staphylococcus aureus

\begin{tabular}{|c|c|c|c|c|c|c|}
\hline \multirow[b]{2}{*}{ No } & \multirow{2}{*}{$\begin{array}{l}\text { Konsentr } \\
\text { asi } \\
\text { Ekstrak } \\
\text { daun } \\
\text { pegagan } \\
(\%)\end{array}$} & \multicolumn{3}{|c|}{$\begin{array}{c}\text { Zona hambat } \\
(\mathrm{mm})\end{array}$} & \multirow{2}{*}{$\begin{array}{l}\text { Jumla } \\
\mathrm{h} \\
(\mathrm{mm})\end{array}$} & \multirow{2}{*}{$\begin{array}{c}\text { Rata- } \\
\text { rata } \\
(\mathrm{mm})\end{array}$} \\
\hline & & $\mathrm{A}$ & $B$ & $\mathrm{C}$ & & \\
\hline $\mathrm{I}$ & $20 \%$ & 15 & I5 & I5 & 45 & $\mathrm{I} 5$ \\
\hline 2 & $40 \%$ & I7 & I8 & 18 & 53 & 17,6 \\
\hline 3 & $60 \%$ & 20 & 20 & 20 & 60 & 20 \\
\hline 4 & $80 \%$ & 22 & $2 \mathrm{I}$ & 22 & 65 & 21,6 \\
\hline 5 & $100 \%$ & 25 & 25 & 25 & 75 & 25 \\
\hline 6 & $\begin{array}{c}\text { Kontrol } \\
\text { positif }\end{array}$ & & & & 0 & \\
\hline 7 & $\begin{array}{c}\text { Kontrol } \\
\text { negatif }\end{array}$ & & & & 5 & \\
\hline
\end{tabular}

Tabel 3 menunjukkan bahwa berbagai konsentrasi ekstrak daun pegagan dapat menghambat pertumbuhan bakteri Staphylococcus aureus dengan terbentuknya zona jernih. Perbedaan zona hambat yang terbentuk dapat dilihat semakin tinggi konsentrasi pada ekstrak daun pegagan maka semakin luas pula zona hambat bakteri Staphylococcus aureus yang terbentuk. Rata-rata zona hambat yang paling tinggi adalah $25 \mathrm{~mm}$ pada konsentrasi $100 \%$ sedangkan rata-rata zona paling rendah adalah $15 \mathrm{~mm}$ pada konsentrasi $20 \%$. Hasil Zona hambat ini lebih besar apabila dibandingkan dengan penelitian Murdiyansah, dkk (2020), yang menggunakan ekstrak etanol daun pegagan pada konsentrasi $30 \%, 50 \%$, dan $70 \%$ hanya dapat memberikan zona hambat $9,3 \mathrm{~mm}, 10,7 \mathrm{~mm}$ dan II,3 mm. Perbedaan ini didisebabkan karena konsentrasi etanol yang digunakan berbeda. Pada penelitian Mudiyansyah (2020) menggunakan etanol $95 \%$, sedangkan dalam penelitian ini menggunakan etanol $90 \%$.

Standar Zona Hambat Antibiotik ampicilin Menurut NCCLS terdapat pada tabel 4

Tabel 4. Interpretasi Zona Inhibisi Staphylococcus aureus Terhadap Antibiotika menurut National Community for Clinical Laboratory Standard

\begin{tabular}{ccccc}
\multicolumn{5}{c}{ (NCCLS) } \\
\hline Jenis & Konsen & \multicolumn{3}{c}{ Diameter Zona Hambat } \\
antibiot & trasi & \multicolumn{3}{c}{ (mm) } \\
\cline { 3 - 5 } ik & cakram & Resist & Intermed & Sensiti \\
& antibiot & en & iet & $\mathrm{f}$ \\
ik & & & \\
\hline $\begin{array}{ccccc}\text { ampicil } \\
\text { in }\end{array}$ & $\mathrm{I} 0 \mu \mathrm{g}$ & $<\mathrm{I} 5$ & I6-I7 & $\begin{array}{c}\geq \mathrm{I} 8 \\
\mathrm{~mm}\end{array}$ \\
\hline
\end{tabular}

Berdasarkan Tabel 4. Diketahui bahwa antibiotik ampicillin sebagai kontrol positif termasuk dalam kategori sensitif terhadap pertumbuhan bakteri Staphylococcus aureus dengan diameter zona hambat $\geq 18 \mathrm{~mm}$. Zona jernih yang terbentuk menunjukkan bahwa bakteri Staphylococcus aureus sensitif terhadap ampicilin menurut National Committee for Clinical Laboratory Standard (NCCLS). Bakteri Staphylococcus aureus dikatakan resisten terhadap antibiotik jika zona jernih yang terbentuk < I5 mm, intermediet I6-I7 mm. Ekstrak daun pegagan mempunyai kemampuan dalam menghambat pertumbuhan bakteri Staphylococcus aureus, hanya saja sensitivitas ampicillin lebih baik dan masih lebih efektif dalam menghambat pertumbuhan bakteri Staphylococcus aureus jika dibandingkan dengan ekstrak daun pegagan .

Kategori daya hambat ditinjau dari diameter zona hambat menurut Stout dalam Menon dan Satria 
(2015) digolongkan dalam 4 kategori seperti yang tersaji dalam tabel 5 .

Tabel 5. Kategori daya hambat ditinjau dari diameter zona hambat

\begin{tabular}{cc}
\hline Diameter & $\begin{array}{c}\text { Respon Hambatan } \\
\text { Pertumbuhan }\end{array}$ \\
\hline$<5 \mathrm{~mm}$ & Lemah \\
\hline $6-10 \mathrm{~mm}$ & Sedang \\
\hline II $-20 \mathrm{~mm}$ & Kuat \\
\hline$>21 \mathrm{~mm}$ & Sangat kuat \\
\hline
\end{tabular}

Sumber : Stout dalam Menon dan Satria, 2015.

Berdasarkan uji daya hambat bakteri Staphylococcus aureus dalam beragam konsentrasi disajikan dalam tabel 6

Tabel 6. Hasil Uji Daya Hambat Ekstrak Daun Pegagan (Centella asiatica) Berdasarkan Kategori Respon Hambat Pertumbuhan

\begin{tabular}{ccc}
\hline $\begin{array}{c}\text { Konsentrasi } \\
(\%)\end{array}$ & $\begin{array}{c}\text { Diameter } \\
(\mathrm{mm})\end{array}$ & $\begin{array}{c}\text { Kategori } \\
\text { respon hambat } \\
\text { pertumbuhan }\end{array}$ \\
\hline $20 \%$ & 15 & kuat \\
\hline $40 \%$ & 17,6 & kuat \\
\hline $60 \%$ & 20 & kuat \\
\hline $80 \%$ & 21,6 & Sangat kuat \\
\hline $100 \%$ & 25 & Sangat kuat \\
\hline
\end{tabular}

Berdasarkan Tabel 6. diketahui bahwa kategori respon hambat pertumbuhan pada berbagai konsentrasi ekstrak daun pegagan yaitu pada konsentrasi 20\%, 40\% dan 60 dengan diameter masing-masing sebesar $15 \mathrm{~mm}$, I7,6 dan $20 \mathrm{~mm}$ termasuk kategori kuat, sedangkan konsentrasi $80 \%$ dan $100 \%$ dengan diameter masing-masing sebesar 2I,6 mm dan $25 \mathrm{~mm}$ termasuk dalam kategori sangat kuat. Berdasarkan hasil penelitian, didapatkan bahwa ekstrak daun pegagan mampu menghambat bakteri Staphylococcus aureus karena terdapat kandungan antibakteri yaitu flavonoid, tanin saponin, fenol dan steroid ditunjukkan dengan adanya zona hambat di sekitar kertas cakram pada media Muller Hinton Agar.

Mekanisme kerja flavonoid sebagai antibakteri yaitu membentuk senyawa kompleks dengan protein ekstraseluler dan terlarut sehingga dapat merusak membran sel bakteri yang diikuti dengan keluarnya senyawa intraseluler (Amalia, dkk., 2017). Mekanisme kerja saponin dengan cara membentuk senyawa kompleks dengan membran sel melalui ikatan hidrogen sehingga dapat menghancurkan permeabilitas dinding sel bakteri (Ramadhan, 20I5)Mekanisme kerja steroid sebagai antibakteri adalah dengan cara merusak membran sel bakteri (Monalisa, dkk., 20I I). Menurut Akiyama (200I) dan Chung (2006), mekanisme kerja tanin sebagai bahan antibakteri antara lain melalui perusakan membran sel bakteri karena toksisitas tanin dan pembentukan ikatan komplek ion logam dari tanin yang berperan dalam toksisitas tanin. Bakteri yang tumbuh dalam kondisi aerob memerlukan zat besi untuk berbagai fungsi, termasuk reduksi dari prekursor ribonukleotida DNA. Adanya ikatan antara tanin dan besi akan menyebabkan terganggunya berbagai fungsi bakteri.

Uji efektivitas antibakteri dengan mengukur presentase (\%) daya hambat menggunakan persamaan Tangapo dalam Oroh, dkk., (2015) Hasil persentase terdapat pada tabel 7

Tabel 7. Hasil Perhitungan Efektivitas Ekstrak

Daun Pegagan (Centella asiatica) Terhadap

Pertumbuhan Bakteri Staphylococcus aureus

\begin{tabular}{llccl}
\hline No & $\begin{array}{l}\text { Konsentrasi } \\
\text { Ekstrak } \\
\text { daun } \\
\text { pegagan } \\
(\%)\end{array}$ & $\begin{array}{l}\text { Rata- } \\
\text { rata } \\
(\mathrm{mm})\end{array}$ & $\begin{array}{l}\text { Presenta } \\
\text { se } \\
\text { Efektivi } \\
\text { tas } \\
(\%)\end{array}$ & $\begin{array}{l}\text { Kategori } \\
\text { Efektivit } \\
\text { as }\end{array}$ \\
\hline I & $20 \%$ & I5 & 37,5 & $\begin{array}{l}\text { Tidak } \\
\text { efektif }\end{array}$ \\
\hline 2 & $40 \%$ & 17,6 & 44 & $\begin{array}{l}\text { Tidak } \\
\text { efektif }\end{array}$ \\
\hline 3 & $60 \%$ & 20 & 50 & efektif \\
\hline 4 & $80 \%$ & 21,6 & 54 & efektif \\
\hline 5 & I00\% & 25 & 62,5 & efektif \\
\hline 6 & $\begin{array}{l}\text { Kontrol } \\
\text { positif }\end{array}$ & 40 & I00 & efektif \\
\hline 7 & $\begin{array}{l}\text { Kontrol } \\
\text { negatif }\end{array}$ & 0 & 0 & $\begin{array}{l}\text { Tidak } \\
\text { efektif }\end{array}$ \\
\hline
\end{tabular}

Efektivitas antibakteri ekstrak daun pegagan terhadap bakteri Staphylococcus aureus terlihat bahwa konsentrasi ekstrak daun pegagan dengan konsentrasi 20\% dan 40\% masuk dalam kategori tidak efektif dan pada konsentrasi $60 \%$, 80\% dan I00\% masuk dalam kategori efektif. Ampicilin sebagai kontrol positif memiliki zona bening dan masuk kategori sangat kuat dan efektif dalam menghambat pertumbuhan bakteri Staphylococcus aureus dibandingkan dengan dengan ekstrak daun pegagan.

Dengan adanya penelitian ini dapat membantu dan memberi informasi bagi masyarakat bahwa ekstrak daun pegagan dapat digunakan sebagai obat alternatif terhadap penyakit infeksi yang disebabkan oleh bakteri Staphylococcus aureus. Penggunaan obat herbal tidak akan memberikan efek samping dalam jangka waktu yang lama. 


\section{Simpulan dan Saran}

Ekstrak Daun Pegagan (Centella asiatica) dengan konsentrasi 60\%, 80\% dan 100\% efektif dalam menghambat pertumbuhan bakteri Staphylococcus aureus sedangkan ekstrak daun Pegagan (Centella asiatica) dengan konsentrasi 20\% dan $40 \%$ tidak efektif dalam menghambat pertumbuhan bakteri Staphylococcus aureus.

Perlu dilakukan penelitian dengan metode yang berbeda seperti metode dilusi dan dilakukan penelitian lebih lanjut secara in vivo.

\section{Ucapan Terima Kasih}

Penulis mengucapkan terima kasih kepada STIKES Guna Bangsa Yogyakarta yang telah memberi dukungan terhadap penelitian ini.

\section{Daftar Pustaka}

Akiyama H, Fujii K, Yamasaki O, Oono T, Iwatsuki T. (200I). Antibacterial action of several tannins against staphylococcus aureus. J.Antimicrob Chemother:; 48: 487 - 491

Alfianthi LK, Fatmawati, Bodhi W. (2016). Uji Aktifitas Antibakteri Ekstrak Ethanol Rimpang Lengkuas Merah (Alpinia purpurata (Vieill) K. Schum) Terhadap Bakteri Klebsiella pneumoniae Isolat Sputum Penderita Bronkitis Secara In Vivo. Jurnal Ilmiah Farmasi, Vol. 05 No. 03, Agustus 202I.

Amalia, A., Sari I., Nursanty, R., (2017), Aktivitas Antibakteri Ekstrak Etil Asetat Daun Sembung (Blumea Balsamifera (L.) Dc.) Terhadap Pertumbuhan Bakteri Methicillin Resistant Staphylococcus Aureus (Mrsa), Prosiding Seminar Nasional Biotik 20I7, ISBN: 978-602-6040I-3-8

Atmojo AT. (2016). Media Mueller Hinton Agar. Tersedia di: http://medlab.id/mediamueller-hinton-agar.html. diakses pada 25 Juli 202I.

Chung JY, Choo JH, Lee MH, Hwang JK. (2006). Anticariogenic activity of macelignan isolatedfrom myristica fragans (nutmeg) against streptococcus mutans. Phytomedicine. I3(4): 26 I - 266

Eliott T. Worthington T, Osman H, Gill M., (2013). Mikrobiologi Kedokteran \&Infeksi, Edisi 4. Penerbit Buku Kedokteran EGC, Jakarta: 23-27.

Hapsari, W.S., Rohmayanti, Yuliastuti, F., Pradani, MPK., (2017), Skrining Fitokimia Ekstrak Etanol Herba Pegagan dan Analisa Rendemen. Prosiding The 6th University Research Colloquium 2017
Jawetz, Melnick, \& Adelberg, (2013). Mikrobiologi Kedokteran. Edisi 25. Penerbit Buku EGC, Jakarta: I94-198.

Karuppiah, Ponmurugan dan Rajaram, Shyamkumar. (2012). Antibacterial Effect of Allium Sativum and Zingiber officinale Rhizomes against Multiple-drugResistant Clinical Phatogens. Asian Pasific Journal of Tropical biomedicine, 2(8), 597-60I.

Kuswiyanto, (2014), Buku Ajar Bakteriologi I, 2, dan 3 analis Kesehatan, Penerbit buku Kedokteran (EGC), Jakarta

Lalamentik G.J., Wewengkang, D.S.,Rotinsulu, H.(2017), Aktivitas Antibakteri Ekstrak Karang Lunak Klyxum Sp.Yang Diperoleh Dari Teluk Manado, Pharmacon, 6(3), 4656

Lolutung, dkk., (2015). Standardisasi Ekstrak Pegagan, Centella Asiatica Sebagai Obat Herbal Terstandar Hepatoprotektor, JKTI, Vol. I7(2): I85-I93

Menon S, Satria A. (2017). Mengkaji Aktivitas Antibakteri Nasturtium officinale dan Ekstrak Etanol Pilea melastomoides terhadap Escherichia coli. Jurnal Farmaka, I5(I), 63-69

Muchtaromah. B (20II). Pengaruh Pemberian Ekstrak Daun Pegagan (Centella asiatica, L. Urban) Terhadap Jumlah Korpus Luteum dan Kebuntingan Mencit (Mus musculus) Betina. Jurnal Berkala Penelitian Hayati, 6D (I5-I8)

Murdiyansah, S., Rasmi, D.A.C., Mertha, I.G. (2020), Centella asiatica Activities towards Staphylococcus aureus and Escherichia coli Growth, Jurnal Biologi Tropis, 20 (3), 499506

Oroh, S.B., Kandou, F.E.F., Pelealu, J.,dan Pandiangan, D. (20I5). Uji DayaHambat Ekstrak Metanol Selaginella delicatula dan Diplazium dilatatum Terhadap Bakteri Staphylococcusaureus dan Escherichia coli. Jurnal Ilmiah Sains, I5(I), 52-58

Putra, I. M. A. S, (2020), Uji Aktivitas Antibakteri Ekstrak Etanol Daun Sirsak (Annonae muricata L.) Dengan Metode Difusi Agar Cakram Terhadap Escherichia coli. Jurnal Ilmiah Medicamento, Vol I(I), I5-19.

Ramadhan, N.S., R. Rasyid., E. S (2015), Daya Hambat Ekstrak Daun Pegagan (Centella asiatica) yang Diambil di Batusangkar terhadap Pertumbuhan Kuman Vibrio cholera secara In Vitro. Jurnal Kesehatan Andalas , 4 (I) 
Sutrisno, E., Adnyana, I.K., Sukandar, E.Y., Fidrianny, I., Lestari, T. (20I4) Kajian Aktivitas Penyembuhan Luka Dan Antibakteri Binahong (Anredera cordifolia (Ten.) Steenis, Pegagan (Centella Asiatica (L.) Urban) Serta Kombinasinya Terhadap Bakteri Staphylococcus Aureus Dan Pseudomonas Aeruginosa Dari Pasien Luka Kaki Diabetes. Bionatura-Jurnal Ilmu-ilmu Hayati dan Fisik, I6(2),78 - 82. 